\title{
An Ayurvedic Management of aamvata: a case study
}

\author{
Dnyaneshwar K Jadhav* \\ Assistant professor, Kaychikitsa department, Shri Dhanwantri Ayurvedic Medical College \& Research Centre, India
}

Submission: September 26, 2018; Published: November 30, 2018

*Corresponding author: Dnyaneshwar K Jadhav, Assistant professor, Kaychikitsa department, Shri Dhanwantri Ayurvedic Medical College \& Research Centre, India - 281401

\begin{abstract}
Ayurved is science of life, which is origin in the vedic culture of India. This science gives more important to Prevention than curative aspect. Ayurved knowledge is described in short \& meaningful code called as sutra. This sutra is itself beauty of Ayurved. Ayurved still stands test to the times. Aamvata is very common disease found in society. This is disease in which vitiation of vata and accumulation of Aam is main parts of pathogenesis. Females are more prone to Aamvata than males. In Modern science there is no sure treatment which cure patient totally. Painkiller and all treatment give temporary relief. In such disease Ayurvedic treatment have the best results, which cure disease from the root. In the Present study, the treatment of a female patient having feature of Aamvata treated with herbal drug which contain tikta katu rasa, dipana properties as shaman chikitsa with langhana, swedana and virechana. There is no any complication was found during treatment. Patient got relief in 2 days only and within 28 days marked improvement was observed in signs and symptoms. Ayurvedic management act on root of pathology of Aamvata and by doing Samparptibhanga it give best result in Aamvata.
\end{abstract}

Keywords: Aamvata; Chikitsa sutra; Ayurvedic Management

\section{Introduction}

Different types of joints diseases found in daily opd. Aamvata is second most common disease found in all joint's disease. As compare to male, it's found more in female. Swelling \& pain in joints is most common symptoms of Aamvata. Madhavnidankar gives nidanpanchaka of Aamvata i.e cause, pathogenesis, symptoms, treatment and complications [1]. In Aamvata, most of moments of patients get restricted due to swelling and pain in joints. Aacharya chakradutta describe chikitsa siddhant of Aamvata [2]. In samhita pain of Aamvata is compare with pain of scorpion bits (vrushikdanchwat vedana).

\section{Case Report}

A 46-year-old female patient came to us with chief compliant of -

i. Ubhya parvasandhi shool (Bilateral finger pain).

ii. Ubhya janusandhi shool-shotha (Bilateral knee pain \& swelling).
iii. Ubhya manibandha shool, Shotha \& sparsha-asahatwa.
iv. Ubhya Ansa-kurpara sandhi shool.
v. Angamarda (Malaise).
vi. Aruchi.(Anorexia)
vii. Morning stiffness.

Patient had above complaints since 2 years.

\section{History of Past Illness \& its Treatment}

a. H/o chikunguniya 2 years before.

b. H/o HTN (under treatment of modern medicine- tab. telvas-40 mg 1-0-0).

c. No H/o Dm / any major surgery.

\section{History of Personal Illness}

The patient was normal 2 years back. Since then patient have been suffering from Ubhya parvasandhi shool (bilateral finger pain), Ubhya janusandhi shool-shotha (bilateral knee pain \& swelling), Ubhya Ansa-kurpara sandhi shool, Ubhya manibandha shool, Shotha \& sparshaasahatwa, Angamarda (malaise), Aruchi (Anorexia), Morning stiffness [3]. For this patient took treatment from different modern doctor but got temporary relief, then she decided to take Ayurvedic treatment. For pure Ayurvedic treatment she came to our clinic.

\section{Personal History}

Occupation: Housewife.

Diet: Mixed diet.

Appetite: Irregular.

Allergy: No history of any drug or food allergy.

Bad Habits: Masheri.

\section{Ashtavidh- Parikshna}

i. Nadi (pulse): $84 / \mathrm{min}$ 


\author{
ii. Mala (stool): Malavashtmbha (constipate) \\ iii. Mutra (urine): Prakrut (regular) \\ iv. Jihwah (tongue): Sama (coated) \\ v. Shabda (voice): Prakrut (clear) \\ vi. Sparsha (touch): Anushna (normal) \\ vii. Drik (eyes): Prakrut (normal) \\ viii. Akriti (built): Sthul (obey).
}

\section{Dashavidha-Parikshna}

a. Prakruti (constitution): Vata pradhana-kapha anubandhi.

b. Vikruti (morbidities): Dosha- Vatapradhana tridosha, Dooshya- Rasa, Meda, Ashti.

c. Satwa (psychic conditions): Madhyama.

d. Sara (excellence of tissue elements): Majja

e. Samhanana (compactness of organs): Madhyama

f. Pramana (measurement of organs): Madhyama

g. Satmya (homologation): Sarva rasa

h. Aharasakti (power of intake \& digestion of food): Madhyama

i. Vyayamasakti (power of performing exercise): Avara

j. Vaya (age): 46 years.

\section{Material and Methods}

\section{Material (Tables 1 \& 2)}

Table 1: Showing material for Management of Aamvata as.

\begin{tabular}{|c|c|c|c|c|}
\hline $\begin{array}{c}\text { Sr. } \\
\text { No }\end{array}$ & Dravya & Dose & $\begin{array}{c}\text { Dura- } \\
\text { tion }\end{array}$ & Anupana \\
\hline 1 & Simhanad Gugul & $250 \mathrm{mg}$ & $2 \mathrm{BD}$ & Luke warm water \\
\hline 2 & Lakshadi gugul & $250 \mathrm{mg}$ & $2 \mathrm{BD}$ & Luke warm water \\
\hline 3 & Tab. Aamsaan & $500 \mathrm{mg}$ & $2 \mathrm{BD}$ & Luke warm water \\
\hline 4 & $\begin{array}{c}\text { Tab. Gandhrva } \\
\text { haritaki }\end{array}$ & $500 \mathrm{mg}$ & $2 \mathrm{HS}$ & Luke warm water \\
\hline 5 & $\begin{array}{c}\text { Rasnasaptakam } \\
\text { kwath }\end{array}$ & $2 \mathrm{TSF}$ & $\begin{array}{c}\text { Twice in } \\
\text { days }\end{array}$ & Luke warm water \\
\hline
\end{tabular}

Table 2: Showing Panchkarma Management of Aamvata as.

\begin{tabular}{|c|c|}
\hline \multicolumn{2}{|c|}{ Panchkarma } \\
\hline Rooksha Swedana & Valukapottli sweda \\
\hline Snehana & Himalya pain relief oil \\
\hline Lepanam & Pidahar lepa \\
\hline Virechana & $\begin{array}{c}\text { Shunthi-siddha eranda tail } \\
(5 \mathrm{ml} \text { at morning })\end{array}$ \\
\hline
\end{tabular}

\section{Method}

a. Center of study: Nakshatra Ayurved panchakarma clinic \& Research canter. b. Type of study: Simple random single case study.

\section{Assessment Criteria [4] (Tables 3-5):}

Table 3: Grading of Sandhishoola (pain).

\begin{tabular}{|c|c|c|}
\hline Sr. no & Severity of Pain & Grade \\
\hline 1 & No pain & 0 \\
\hline 2 & Mild pain & 1 \\
\hline 3 & Moderate, but no difficulty in moving & 2 \\
\hline 4 & Much difficulty in moving the body parts & 3 \\
\hline
\end{tabular}

Table 4: Grading of Sandhishotha (swelling).

\begin{tabular}{|c|c|c|}
\hline Sr.no & Severity of swelling & Grade \\
\hline 1 & No swelling & 0 \\
\hline 2 & Slight swelling & 1 \\
\hline 3 & Moderate swelling & 2 \\
\hline 4 & Severe swelling. & 3 \\
\hline
\end{tabular}

Table 5: Grading of Sparshasahatwa (tenderness).

\begin{tabular}{|c|c|c|}
\hline Sr.no & Severity of Tenderness & Grade \\
\hline 1 & No tenderness & 0 \\
\hline 2 & Subjective experience of tenderness & 1 \\
\hline 3 & Wincing of face on pressure. & 2 \\
\hline 4 & $\begin{array}{c}\text { Wincing of face and withdrawal of the affected part } \\
\text { on pressure }\end{array}$ & 3 \\
\hline
\end{tabular}

\section{Discussion}

\section{Discussion on Vhyadhi}

Vitiation of Vata Dosha and formation of Aam together caused Aamvata. Ayuveda said that, 'Roga sravepi mandagni' i.e most of disease occurs due to Mandagni. This Mandagni is the main cause of production of Aam [5]. Improving Jathra-agani and removal of Ama was the aim of treatment in Aamvata along with vatahara treatment Yogaratnakara said that Langhana is best treatment of Aam. We advised Langhana in the form of Laghu Aahar to the patient. Aamvata is an Amasayotha vyadhi and Rasaja Vikara. Langhana is the first line of treatment in such conditions [6].

\section{Hetu of Aamvata as}

\section{Ahar}

a. Improper and irregular diet causes the disturbance of vatadosha.

b. Dry foods like biscuit and all bakery products.

c. Sabudana, Dadhi

d. Paryushita anna

e. Grains: Navadhanyak. (Daily plenty of rice in diet).

f. Daily non-veg (mutton \& chicken)

\section{Vihar}
i. Working in water
ii. Suppression of natural urge (Mala-Muta vega dharan). 
iii. Diwaswap.

iv. Manasika nidan- Chinta and vegavrodha causes vata vrudhi (Table 6).

Table 6: Showing samprapti Ghatak.

\begin{tabular}{|c|c|c|}
\hline \multicolumn{2}{|c|}{ Sanprapti Ghatak } \\
\hline \multirow{2}{*}{ Dosh } & Vata & Sheet, Ruksha, chala - guna vrudhi \\
\cline { 2 - 3 } & Kafa & Sheet, guru - guna vrudhi. \\
\hline Dushya & Rasa, Rakta. \\
\hline Adhishtana & \multicolumn{2}{|c|}{ Sandhi } \\
\hline
\end{tabular}

All above hetu (causes) leads to production of Aama in body which circulates in whole body (via vyan-vayu) \& accumulates in sandhi (joints) along with the pathogenicity or vitiation of vata leads to Aamavata.

\section{Discussion on Medicine (Sampraptibhnga)}

a. Simhanaad Gugul: Yogratnakara mentioned that Aamvata is Rogadhikara of Simhanaad guggul [7] its contain Suwarnamakshika, Trifala, Shudha gandhaka, Shudha gugul and Eranda tail which has Laghu, Ruksha, Ushna, Tikshna propertie. It's do Ama-Pachan (bio-toxin neutralizing), Shothaghna (oedema reducing), Deepan (enzyme activating), Balya (energy enhancing), Shoolghna (analgesic). Its enhances Agni-Bala and alleviates the Aam and prevents the further formation of Ama. which helps in breaking the Samprapti (pathogenesis) of Aamavata [8].

b. Lakshadi Gugul: This drug mentioned under Bhishjyaratnawali Aamvatarogadhikara-90-95. Its contain Laksha, Asthisamhrut, Kakubha, Ashwagandha, Nagbala, Gugul. This drug do healing of bones which get degenerated in Aamvata.

c. Tab.Aamsaan: Its contain ova, amlavetas, musta, jire, vidanga, trifala, chitrak, chvya, sunthi, mire, pipli, bahava, shauktik bhasma - which is digestive and aampachak.

d. Rasnasaptakam kwath: Its contain Rasna, Amruta, Aragvadha, Devdaru, Trikantaka, Ernada, punarnava, Shunthi. Its act as shoolaghna (analgesic), vata-kafa shamaka, immunomodulator, anti-inflammatory, carminative, appetizer $[9,10]$.

e. Gandharva haritaki: Gandharva haritaki is polyherbal Ayurvedic medicine. Contains of this medicine are erand tail, balharitaki, sunthi, sandhav and savarchal lawana.it has purgative and laxative action. Gandharva haritaki evacuates bowel and removes toxins from body.

f. Rooksha - Valukapottli sweda: In Aamavata, we advised Rukshasweda in the form of Valukapottali. It helps in pacifying vitiated Vata Dosha thus leads to relieve pain and stiffness. Swedana have been specially indicated in the presence of Stambha, Gaurava and Shula. So here also we advised valuka pottali sweda [11].

g. Snehana with Himalaya pain Relif Oil: its contain sesame oil, drumstick, sweet flag, country mallow, cedarwood, ginger. sesame oil helps soften and smoothen skin which do vatashmana, drumstick help reduce pain (analgesic property), country mallow helps to relax the muscles-joints and helps for healing, cedarwood relives muscles ache, ginger relive swelling (anti-inflammatory property ), sweet flag relives neuromuscular pain. In short, this oil help to relive the pain \& Swelling by vatashaman and causes Aamapachana on local application.

h. Lepanam with Pidahar Lepa: Its contains halad, daruhalad, vekhnda, shuntha, kalabol, gugul, multani mati and Kapoor, nilgiri oil, navsagar as praksheep dravya. Its act as shoolaghnha (analgesic property), shotaghna (anti-inflammatory property).

i. Virechana -Shunthi-siddha eranda tail $(5 \mathrm{ml}$ at morning): Shunthi is best aampachk, shothaghan, and eranda tail is one of the best drug mentioned in Aamvata, Both drug together work as vata-kafa shamak, immunomodulator, shothahara (antiinflammatory) [12].

\section{Observation \& Result}

Patient got relief in Swelling and tenderness within 2 days. Rest improvement in all symptoms found within 7 days. After 28th days follow up there is nearly nil of all symptoms. After our successful treatment, we took follow up of patient till next 3 months on each 15 days. I found that there is nil of all symptoms (except occasionally little pain in knee joints, we can consider its normal, as per age of patient and chronic disease) (Tables 7-12).

Table 7: Assessment of sandhi-shool.

\begin{tabular}{|c|c|c|c|c|}
\hline \multicolumn{2}{|c|}{ Left } & Name of Joint & \multicolumn{2}{c|}{ Right } \\
\hline Before & After & & Before & After \\
\hline 3 & 0 & Parvasandhi & $\mathbf{3}$ & $\mathbf{1}$ \\
\hline 2 & 0 & Janusandhi & $\mathbf{3}$ & $\mathbf{1}$ \\
\hline 3 & 0 & Manibandha & $\mathbf{3}$ & $\mathbf{0}$ \\
\hline 1 & 0 & Ansa sandhi & $\mathbf{1}$ & $\mathbf{0}$ \\
\hline 1 & 0 & Kurpara sandhi & $\mathbf{1}$ & $\mathbf{0}$ \\
\hline
\end{tabular}

Table 8: Assessment of sandhi-shoth.

\begin{tabular}{|c|c|c|c|c|}
\hline \multicolumn{2}{|c|}{ Left } & Name of joint & \multicolumn{2}{c|}{ Right } \\
\hline Before & After & & Before & After \\
\hline 2 & 0 & Janusandhi & 3 & 1 \\
\hline 3 & 0 & Manibandha & 3 & 0 \\
\hline
\end{tabular}

Table 9: Assessment of sparshasahatwa (tenderness).

\begin{tabular}{|c|c|c|c|c|}
\hline \multicolumn{2}{|c|}{ Left } & Name of Joint & \multicolumn{2}{c|}{ Right } \\
\hline Before & After & & Before & After \\
\hline 3 & 0 & Manibandha & 3 & 0 \\
\hline
\end{tabular}

Table 10: Assessment of angamarda (malaise).

\begin{tabular}{|c|c|}
\hline \multicolumn{2}{|c|}{ Angamarda (Malaise). } \\
\hline Before & After \\
\hline 3 & 0 \\
\hline
\end{tabular}




\section{Orthopedics and Rheumatology Open Access Journal (OROAJ)}

Table 11: Assessment of Aruchi (anorexia).

\begin{tabular}{|c|c|}
\hline \multicolumn{2}{|c|}{ Aruchi. (anorexia) } \\
\hline Before & After \\
\hline 2 & 0 \\
\hline
\end{tabular}

Table 12: Assessment of Morning stiffness.

\begin{tabular}{|c|c|}
\hline \multicolumn{2}{|c|}{ Morning stiffness } \\
\hline Before & After \\
\hline 3 & 0 \\
\hline
\end{tabular}

\section{Conclusion}

Ayurveda has unique concepts with all disease called as chikitsa siddhanta, which work and stand test to the time. Since the therapy for Aamvata has limitation in other pathies, Ayurvedic management of Aamvata is one of the most effective therapy. This is one case study which give fast relief to patient which break old thinking of society i.e slow Result of Ayurvedic treatment.

\section{Acknowledgement}

I feel highly grateful to Dr. Vivek chandurkar, Professor, and HOD, Department of Kayachikitsa, S.G.R. Ayurveda College, solapur for the valuable guidance during post-graduation study, which is useful for all this Research work.

\section{References}

1. Dr. Brahmananda tripathi, madhavnidanam (2014) Sanskrit complimentary of madhukosha by vijyarakshita and shrikanthadutta, Edited with vimala madhudhra Hindi commentary, (edn 2014), volume-1, aamvata nidana, Adhya.25, verse no.1-5, chukhmbasurbharti publication, Varanasi, India, pp. 451.
2. Chakrapani Datta (2010) Chakradatta commentary by Indradev Tripathi. Amavatarogadhikara 25/31-36. Varanasi: Chaukhamba Sanskrit Sansthan. pp.167-168.

3. Dr. Brahmananda tripathi, madhavnidanam (2014) Sanskrit complimentary of madhukosha by vijyarakshita and shrikanthadutta. Edited with vimala madhudhra Hindi commentary, (edition 2014), volume-1, aamvata nidana, adhya.25, verse no.6, chukhmbasurbharti publication, Varanasi, pp. 451.

4. Ashish et al. (2017) A Case study on Amavata (Rheumatoid arthritis). 2(5): 646-651.

5. Tripathi Ravidatta, Charaka samhita (Vidyamanorama Hindi commentary, (Edi-2009) Chaukhamba Sanskrit Pratishthan, Delhi, Nidan stan, Aadhya no. 8(31): 542.

6. Tripathi Ravidatta, Charaka samhita with Vidyamanorama Hindi commentary, (Edi-2009), Chaukhamba Sanskrit Pratishthan, Delhi, Sutra stan, Aadhya no.23(25): 319.

7. Vd.deshpande, Yashsavi aushdhi, $\left(2^{\text {nd }}\right.$ edn), Ayurvidya prasaraka mandal publication, sion, Mumbai; prakarana Number. 6, Gugul kalpa prakarana, pp. 188.

8. Das Govinda, Bhaishajya Ratnavali, Hindi commentary by Ambikadatta Shastri, Chaukhambha Prakashana, Varanasi, (Edi-2014), Amavata chikitsa, adhya no-29, verse no.181-189, pp. 628.

9. Vd.Deshpande, Yashsavi aushdhi, second edition, Ayurvidya prasaraka mandal publication, sion, Mumbai; prakarana Number.10, kwath kalpa prakarana, pp. 221.

10. Gandharva haritaki

11. Tripathi Ravidatta, Charaka samhita with Vidyamanorama Hindi commentary, (Edi-2009), Chaukhamba Sanskrit Pratishthan, Delhi, Sutra stan, adhya no. 22(11): 309.

12. Panthulu Raghupathy Goud et al. (2016) The effect of Ayurvedic drug when used as Disease modifying antirhumatic drugs (DMARDs) in Aamvata: Int J Res Ayuveda Pharm 2012 Jan-feb Aug 3(1): 29.

\section{Your next submission with Juniper Publishers} will reach you the below assets

- Quality Editorial service

- Swift Peer Review

- Reprints availability

- E-prints Service

- Manuscript Podcast for convenient understanding

- Global attainment for your research

- Manuscript accessibility in different formats

( Pdf, E-pub, Full Text, Audio)

- Unceasing customer service

Track the below URL for one-step submission https://juniperpublishers.com/online-submission.php 